Textures and Microstructures, 1988, Vols. 8 \& 9, pp. 719-736

Reprints available directly from the publisher

Photocopying permitted by license only

(C) 1988 Gordon and Breach Science Publishers Inc.

Printed in the United Kingdom

\title{
Natural and Simulated (10.4) Pole Figures of Polycrystalline Hematite
}

\section{H. QUADE}

Institute of Geology and Paleontology, Technical University of Clausthal, Federal Republic of Germany

(Received August 11, 1987)

\section{Dedicated to the memory of Professor Günter Wassermann}

Qualitative (10.4) pole figures of hematite have been generated by simulating the rotative arrangement of $c$ axes on planes of preferred simple shear. The procedure of simulation is described which consists in geometric operations varying the degree of texture anisotropy and homogeneity. Comparisons are made between predicted orientation diagrams and natural textures of high-grade hematite ores from Precambrian deposits of North and South America, Africa, and Australia. The mechanisms of preferred orientation of hematite in ores are explained in terms of changing metamorphic conditions and variations in amount of simple rotational shear.

KEY WORDS: Hematite, simple shear, mathematical simulations, pole figures

\section{INTRODUCTION}

In Precambrian banded iron formations (BIF) hematite may be enriched to such extremely high concentrations, so that it reacts as a distinct rheological mass generating domains of preferred plastic deformation by folding and ductile shear. Regional metamorphism, characterized by elevated pressure, temperature, and thermodynamic activation of ions, triggered the secondary hematite enrichment and promoted complex tectonometamorphic processes that control the evolution of specific ore fabrics; yet the inherent mechanisms and rates of solid-state diffusion and dislocation creep 
in polycrystalline hematite as well as in the surrounding rocks are still far from understood (Hobbs, 1981).

Textures of naturally deformed hematite ores were initially described from individual samples of various locations (Neff and Paulitsch, 1960; von Gehlen, 1960; Ambs, 1966). More systematic investigations concerned recrystallized banded ores from Precambrian deposits of central Sweden and North America (HennigMichaeli, 1976, 1977a; Wagner et al., 1977). First approaches to the interpretation of hematite fabrics in their natural tectonic context have been obtained by comparative studies of the tectonic inventory and textures of iron ore deposits in Minas Gerais, Brazil (Hackspacher, 1979; Rosière, 1981; Guba, 1982; Esling et al., 1981; Quade and Walde, 1982; Evangelista, 1984; Chemale, 1987). A special interest in such investigations arose from the experience that there is a strong correlation between fabric type and degree of preferred orientation of hematite in high-grade ores and the behavior of such ores in direct reduction processes (Walde et al. 1983).

The present paper is concerned with a qualitative approach to the classification and geometric interpretation of natural (10.4) texture diagrams of hematite on the basis of simulated texture configurations, thus attempting a first systematization with regard to geological conditions of their evolution and its applicability to technological evaluation.

\section{HIGH-GRADE HEMATITE ORES}

The solid state reduction of iron ores in electric arc furnaces and oxygen converters, called direct reduction, is an expanding technology on the international iron ore market though its impact is not yet very important. It has been estimated (Astier, 1981) that around 1990 a supply of about 40 Million tons of high-grade ores or concentrates or, even, superconcentrates may be needed for direct reduction plants. Direct reduction requires, as a rule, high-grade natural ores with low content of gangue and impurities and special physical qualities as to granulation, reductibility and strength during reduction. In order to meet the specifications, which change with ore type and buyer's requirement, the run-of-mine products have to 
be sized, either as lump ( 8 to $25 \mathrm{~mm}$ ) or as agglomerate (Pellets: $<2 \mathrm{~mm}$, sinter feed: $<8$ to $10 \mathrm{~mm}$ ), apart from purification by magnetic separation or/and flotation.

The principal natural source of raw materials of direct reduction quality are hard high-grade hematite ores within hundreds of meters thick sequences of banded to laminated hematite bearing rocks rich in quartz or/and carbonate with a mean iron content of about $37 \%$. Such "jaspilites" and their strongly sheared equivalents, the "itabirites", as well as totally recrystallized varieties are widely distributed in stable cratonic regions of lower Precambrian age (older than $2 \mathrm{Ga}$ ). The high-grade hematite ores occur as concordant bands or discordant lenses and are due to a post-sedimentary relative iron enrichment by which the iron content rose to remarkable concentrations above $60 \%$, so that high-grade ores are nearly monomineralic hematite rocks. Whereas for low-temperature varieties without significant deformation (jaspilites) a diagenetic or/and supergene enrichment of iron is assumed (Morris, 1985), in itabiritic sequences it is the tectonometamorphic imprint on the ore bearing sequences which promoted the mobilization of iron and impurities and the selective high concentration of iron in distinct zones at different scales.

In middle to lower crust levels of Precambrian terranes, which contain infolded piles of banded iron formations, low- to mediumgrade metamorphism (greenschist to amphibolite facies), accompanied by regional deformation, defines the conditions of tectonometamorphic processes. The most obvious structural feature of tectonized protores as well as of derived high-grade hematite ores is a penetrative foliation $S_{1}$ which exhibits pronounced schistosity and may reflect the older sedimentary layering. A strong mineral lineation is ubiquitous on such planes corresponding to the direction of maximum elongation or extensional flow. Often secondary planar elements are developed which attain similar characteristics, as, for instance, cleavage planes that are in axial plane position to dominant fold structures of sometimes different generations $\left(S_{2}, S_{3}\right.$, etc.) or shear bands or thrusts. These planar discontinuities, under conditions of elevated temperatures (up to more than $500^{\circ} \mathrm{C}$; see Müller et al., 1986, for reference), are zones of heterogeneous deformation and of differential mobilization of chemical components. They were formed by simple rotational and ductile shear 
in a rock environment which originally suffered a homogeneous deformation by flattening (pure shear). There may be quite complex deformation patterns resulting (Hackspacher, 1977; Rosière, 1981; Guba, 1982; Evangelista, 1984; Chemale, 1987), yet the principal effect of deformation, preferred orientation of crystals, and intrafacial recrystallization is geometrically controlled by the surfaces which bound the shear zones and act as planes of ductile shear. The changes in degree of deformation and of preferred orientation of hematite seem to be due to variations in amount of simple shear (cf. Coward, 1976).

Typical microphotographs of Precambrian high-grade ores are illustrated in Figure 2. In all samples investigated the oldest oxide mineral phase is magnetite transformed to martite from which the first hematite generation resulted by progressive recrystallization. Under influence of pure shear hematite was transformed to the platy specularite variety which tends to align with (0001) preferably parallel to the shear plane which in most cases corresponds to the dominant foliation plane. Ore types, which only suffered a lowgrade metamorphism (Müller et al., 1986; 140-210 ${ }^{\circ} \mathrm{C}$ ) and a predominantly pure shear by flattening, show fine-grained hematitequartz intergrowths and exhibit textures of more or less randomly orientated hematite crystals (Figure 2a: jaspilite from the Sishen deposit, SAU), even in the case of a primary enrichment of hematite in bedding-parallel layers (Figure 2b: jaspilite from the Hamersley Range, Australia). Martite relics are ubiquitously conserved in such ores (Figure 2c: jaspilite from Mt. Newman, Australia). The increasing tectonic imprint under conditions of progressive metamorphic grade gave rise to a texture anisotropy by preferred orientation of hematite, accompanied by diffusioncontrolled mobilization of the chemical components and by "purifying" recrystallization of hematite. Such processes were, above all, bound to zones of pronounced differential shearing (simple shear) which may be bedding-parallel foliation planes or shear bands or thrust zones at scales of millimeters to meters. The finally resulting ore fabric is a platy arrangement of specularite parallel to the shear plane exhibiting straight and non-meshed grain boundaries (Figure 2e: high-grade ore from the Cauê mine, Brazil) and, in views perpendicular to the $X Z$ plane of a sample, fiber-like textures of specularite (Figure 2d: high-grade ore from the Republic mine, 
Michigan; Figure 2f: high-grade ore from the Aguas Claras mine, Brazil).

\section{PROCEDURE OF TEXTURE ANALYSIS AND SIMULATION}

The trigonal hematite is isostructural with corundum and of rhombohedral symmetry. Its unit cell is to be described by the length of an edge of the unit rhombohedron, $a_{i}$, and by the angle between two edges, $\alpha$. A non-primitive hexagonal cell of three times the volume is more often used for the denomination of indices. Oxygen forms planes parallel to (0001) of the hexagonal cell or (111) of the rhombohedral cell and is nearly hexagonal close packed. Cations occupy two-third of the octahedral interstitial sites which are distorted because of departure from hexagonal close packing (see Lindsley, 1976, for reference and discussion).

Three $a_{i}$ axes and two sets of three (10.4) faces twisted by $60^{\circ}$ correspond to the position of a single $c$ axis or pole to (0001) of hematite (see Figure 1). Textures of polycrystalline hematite will have triad axes of symmetry only in the very special cases (a) that

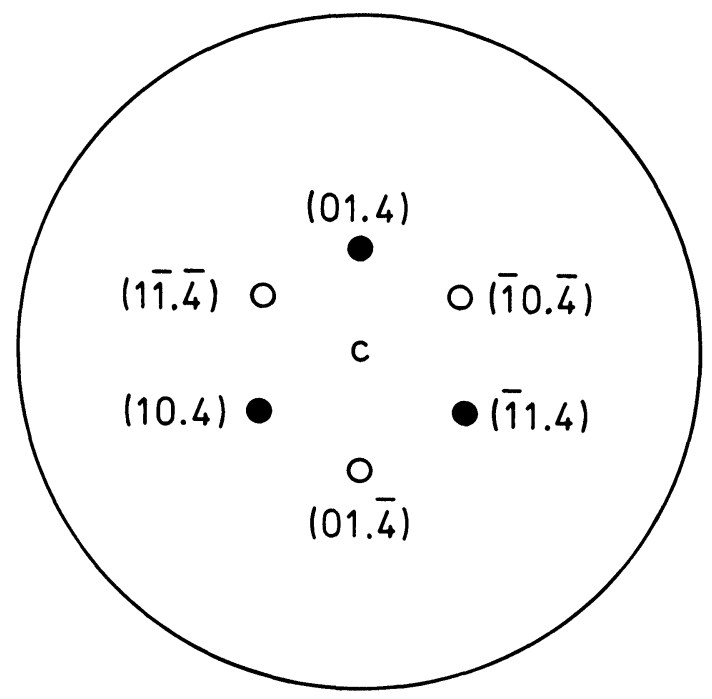

Figure 1 Single crystal orientation of hematite with $c$ axis and (10.4) faces. 
the $c$ axes as well as the $a_{i}$ axes of all individuals are congruent in orientation and polarity (single-crystal texture) or (b) that the $c$ axis and non-equivalent $a_{i}$ axes coincide in their spatial position (pseudo-single-crystal texture). Such textures commonly cannot be expected in natural rock environments as they would require extremely special conditions of formation. Hence natural textures of polycrystalline hematite exhibit orientation patterns that are characterized either by nearly diad axes of symmetry or by rotative point maxima.

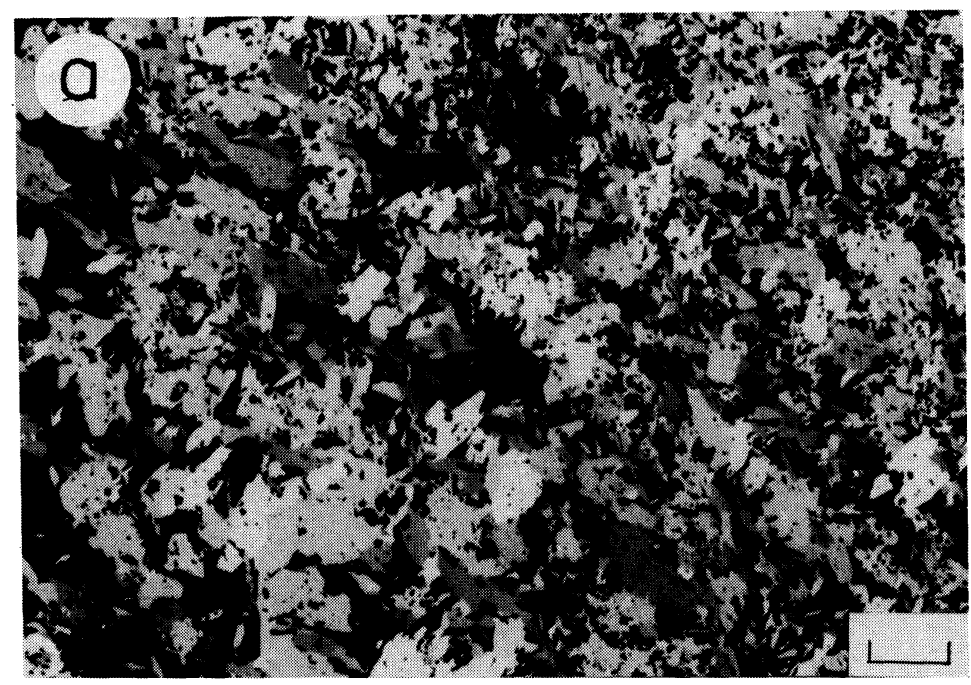

Figure 2 Microphotographs of high-grade hematite ores: (a) Jaspilite with weak orientation of hematite (Sishen deposit, Postmasburg, northern Cape Province, Republic of South Africa; arbitrary section, crossed nicols, scale bar $200 \mu$ ); (b) Low-grade jaspilite with hematite-rich layers (Hamersley Range, Western Australia; $X Z$ section, crossed nicols, scale bar $100 \mu$ ); (c) Typical appearance of sheared high-grade ore with (0001) parallel to foliation (Republic mine, Marquette Range, Michigan, USA: $X Z$ section, parallel nicols, scale bar $200 \mu$ ); (d) High-grade ore with relictic martite and weak preferred orientation of hematite (Mt. Newman, Western Australia; arbitrary section, SEM photograph, scale bar 50 $\mu$ ); (e) Strongly oriented and recrystallized hematite ore (Cauê mine, Itabira district, Minas Gerais, Brazil; oblique view to foliation, SEM photograph, scale bar $50 \mu$; cf. Figure 5d); (f) Platy ore with strong preferred orientation (Aguas Claras mine, Quadrilátero Ferrífero, Minas Gerais, Brazil; $X Z$ section, SEM photograph, scale bar $10 \mu$; cf. Figure 5f). 

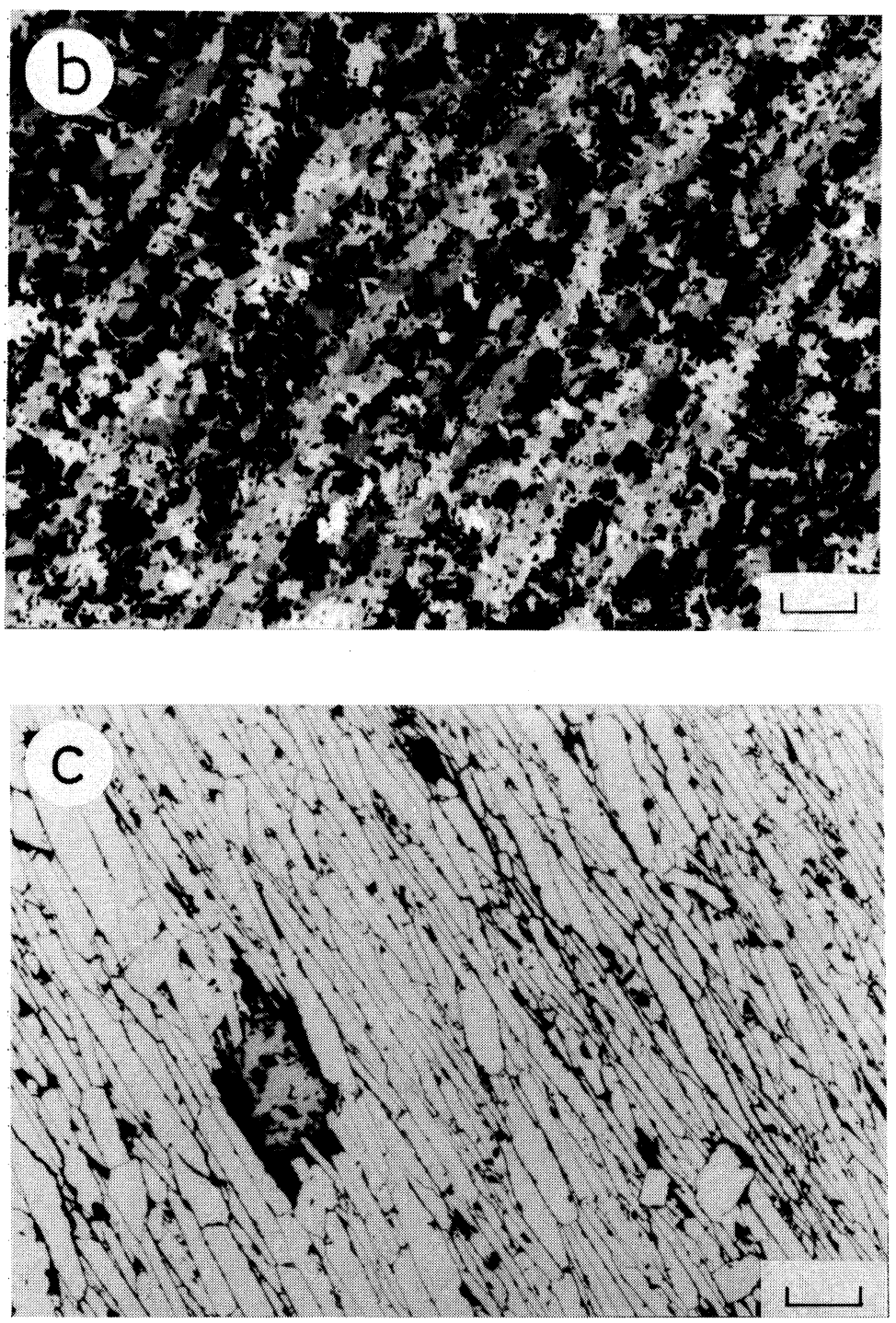

Figure 2 (Continued) 

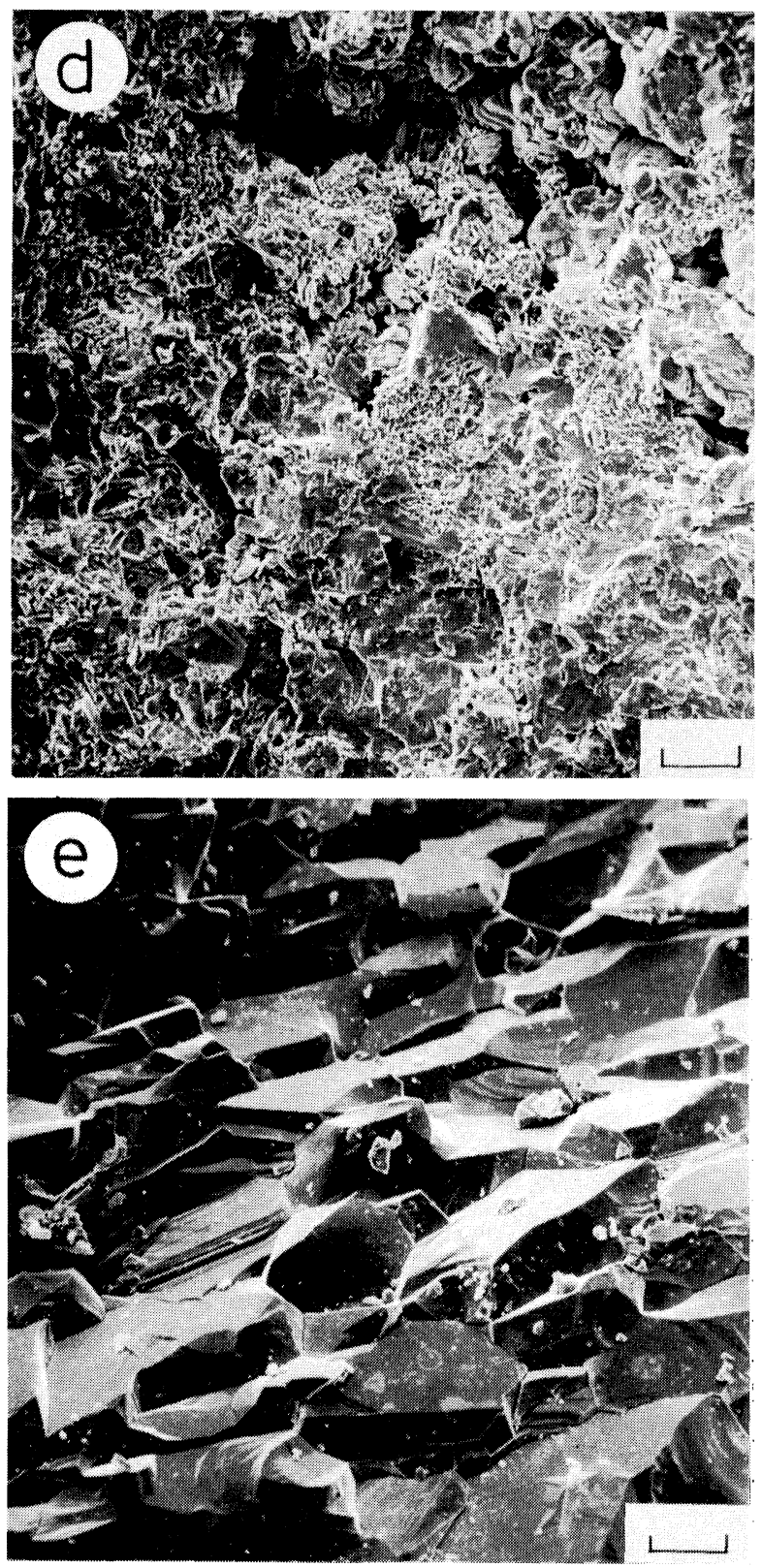

Figure 2 (Continued) 


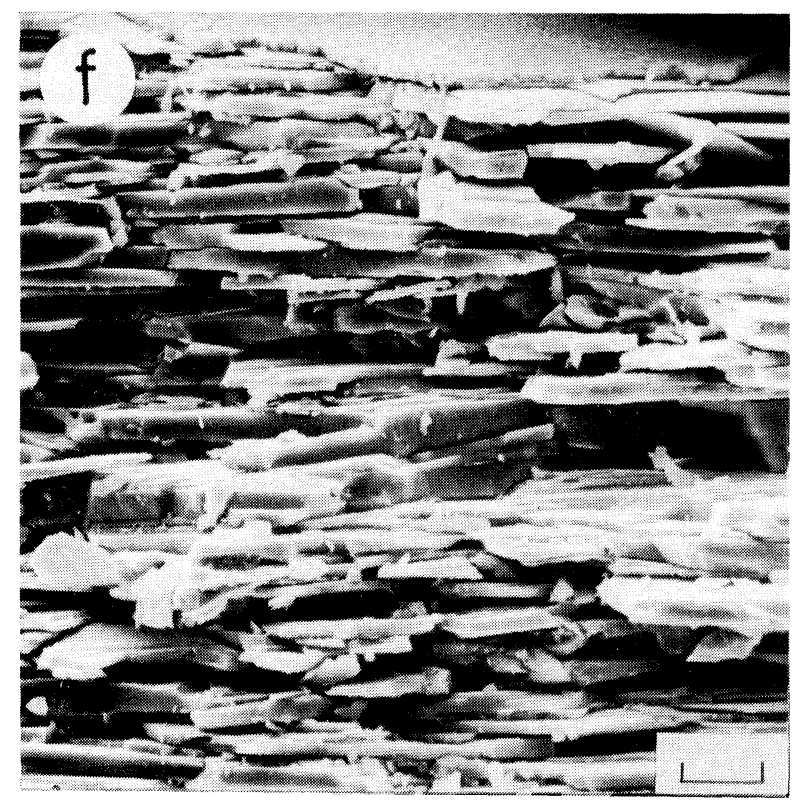

Figure 2 (Continued)

The aim of the simulation of (10.4) pole figures of polycrystalline hematite is twofold. First, by defined geometric operations it was attempted to create texture configurations which correspond to natural hematite fabrics. Second, as it is not possible to deduce the orientation distribution of hematite crystallites in a sample directly from (10.4) pole figures, a graphic approximation was searched for that facilitates a kinematic interpretation of the orientation of hematite in the context of structural analysis of iron ore deposits and which, by this, permits a classification of ore types as to their physical properties. A first qualitative approach to such a simulation has been presented recently by Mager et al. (1985).

The preferred orientation of (10.4) lattice planes of the trigonal hematite were measured by X-ray (covering the field from $0^{\circ}$ to $80^{\circ}$ of inclination) in a great variety of high-grade ores from different Precambrian deposits in North and South America, Africa, and Australia. Because of the coincidence of the Bragg angles, such a qualitative $\mathrm{X}$-ray analysis does not allow to discriminate the six equivalent poles to (10.4) that correspond to one $c$ axis (Figure 1), 
without calculating the complete orientation distribution function (Bunge, 1981). As no quantitative interpretation of $c$ axes orientation is attempted as yet, the inherent crystallographic multiplicity effect has been neglected (cf. Starkey, 1987). In all cases the dominant foliation plane (kinematic $X Y$ plane) of the samples, which often contains a pronounced mineral lineation in the direction of $X$, was taken as the geometric reference element. It corresponds to the plane of projection of the diagrams which reproduce the poles to (10.4) faces (equal area projection, lower hemisphere). The centre of the diagrams thus represents the pole to the foliation plane.

The starting point of the present simulation is the observation that in samples, which did not suffer any deformation, the $c$ axes of hematite are randomly orientated or scattered obliquely to the foliation plane, with a slight trend to verticality. By progressive orientation they become more and more concentrated and set upright. This geometric configuration of $c$ axes may be described by more or less regular cones with varying apical angles, the axis of which are perpendicular to the foliation plane. With increasing preferred orientation the apical angle decreases, and by an imposed shear the cones become elliptically deformed in the direction of maximum extensional flow (Fig. 3). Such cones intersect with the projection plane as circles or ellipses, commencing at $80^{\circ}$ with a broad maximum in the centre of the diagram and below $35^{\circ}$ passing to a ring-like maximum around the centre which is free of pole

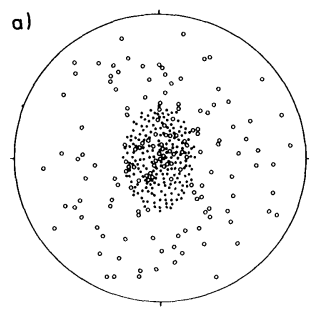

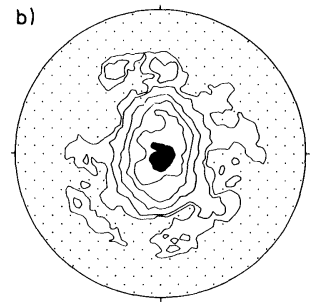

$0.5-1.0-3.0-5.0-7.0-9.0 \%$

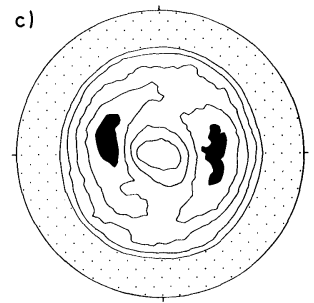

$0.5-1.0-1.5-2.0-2.5 \%$

Figure 3 Procedure of simulation of (10.4) pole figures of hematite: (a) Simulated $c$ axis fabric for an anisotropy of $40^{\circ}$ and $3: 2$ homogeneity (open circles: background axes, created by a random number generator; full circles: simulated axes within the field of $40^{\circ}$ and $3: 2$ ); (b) Contour line diagram of the $c$ axes; (c) Contour line diagram of the calculated (10.4) pole positions. 
positions, corresponding to increasing parallelism of (0001) planes and the foliation plane.

In this sense two principal distribution patterns of natural hematite ores may be distinguished (cf. Figure 5). Ores, which under the microscope show a pronounced parallelism of (0001) planes in $X Y$, exhibit a circular arrangement of the (10.4) poles at $30-40^{\circ}$ away from the centre which corresponds to the position of the imaginary mean $c$ axis of the texture. Ores without a visible preferred orientation of hematite are characterized by a broad (10.4) point maximum with outwardly decreasing intensities (Mager et al., 1985).

The spectrum of possible geometric configurations was simulated by modifying the arrangement of (0001) poles ( $=c$ axes) in relation to the projection plane (diagram) and by calculating the equivalent (10.4) poles which are at about $35^{\circ}$ to the (0001) pole position (Pauling and Hendricks, 1925: $34.7^{\circ}$; Ramdohr and Strunz, 1967; 34. $8^{\circ}$; Lindsley, $1965: 34.3^{\circ}$; ASTM: $34.4^{\circ}$ ). The different degrees of preferred orientation (texture anisotropy) were simulated by varying the apical angle of the cone (from $80^{\circ}$ to $10^{\circ}$ ), i.e., the field of the diagram occupied by (0001) poles. As a measure of orientation homogeneity the relation of the cone axes was taken (circle $=3: 3$, ellipses $3: 2$ and $3: 1$ ), that means by arranging the pole positions in a progressively smaller area of the above field, thus indicating an increasing shear effect.

First, for all diagrams a background of 150 (0001) poles was created by using a random number generator to establish a normal distribution of points in the $80^{\circ}$ 's field of the circle (Figure 3a). Then this pattern was overlain by $200(0001)$ pole positions arbitrarily distributed within a defined circle or ellipse. Figure $3 a$ shows the example of the simulated (0001) pole figure of a cone with an apical angle of $40^{\circ}$ and a relation of $3: 2$ of its axes. The elliptic elongation in north-south direction of the diagram would correspond to the $X$-coordinate of a natural foliation plane (kinematic $X Y$ plane), due to extensional flow on a shear plane. Figure $3 \mathrm{~b}$ is a contour line diagram of this point fabric. The derived (10.4) pole configuration is illustrated in Figure 3c, which shows two banana-shaped maxima symmetrically arranged in a distance of about $35^{\circ}$ to the central maximum of (0001) poles. Similar pole figures have been obtained by Esling et al. (1981) who applied neutron diffraction to the 
analysis of $c$ axes and X-ray diffraction to the analysis of (10.4) faces of the same samples.

\section{INTERPRETATION OF (10.4) POLE FIGURES}

The calculated (10.4) pole figures are shown in Figure 4 while Figure 5 illustrates comparatively some examples of natural hematite textures from different ore deposits. In all simulated diagrams the background of $150 \mathrm{c}$ axes, calculated by a random number generator, is the same. The numbers below the diagrams indicate the range of frequency of pole positions in relation to the entire population of 350 .

The texture of highest isotropy and homogeneity is that of the $3: 3$ diagram at $80^{\circ}$. The $c$ axes are statistically scattered over the

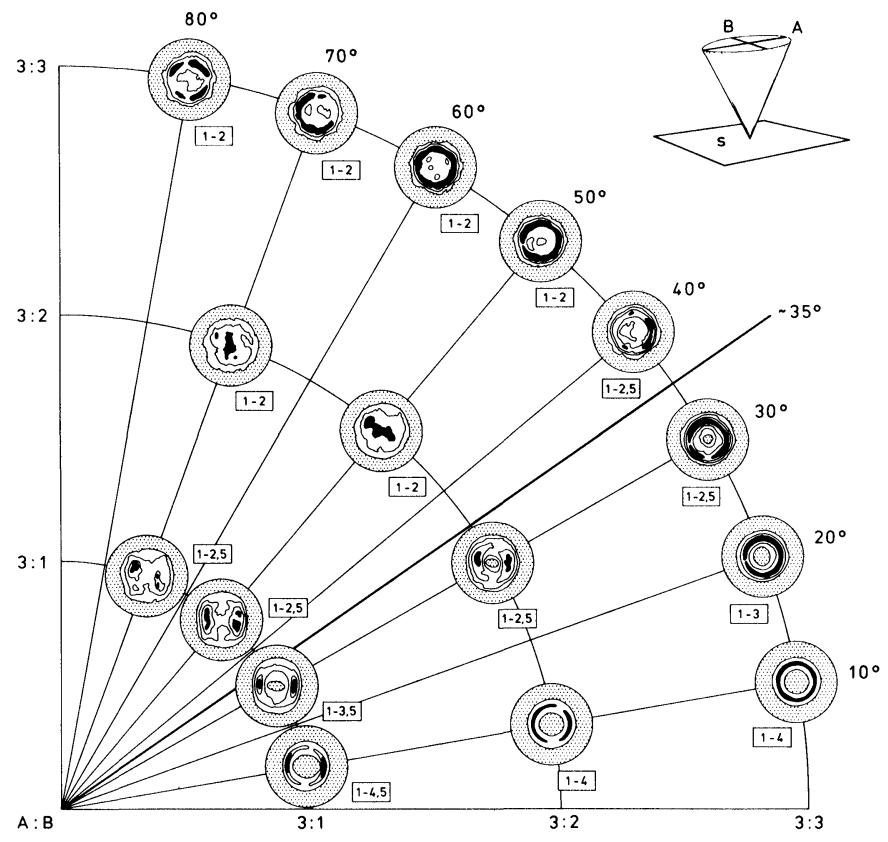

Figure 4 Diagram of the simulated (10.4) pole fabrics with increasing anisotropy $\left(80^{\circ}\right.$ to $\left.10^{\circ}\right)$ and increasing homogeneity $(3: 1$ to $3: 3)$ of $c$ axes arrangement. The sketch illustrates the position of a distribution cone of $c$ axes with relation to a foliation plane (= plane of projection). 


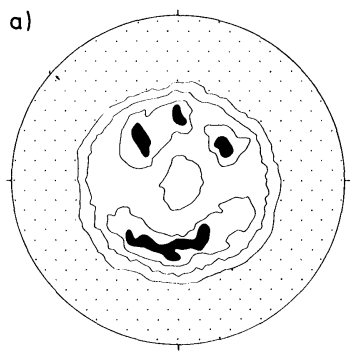

$1-2-3-3.8 \%$

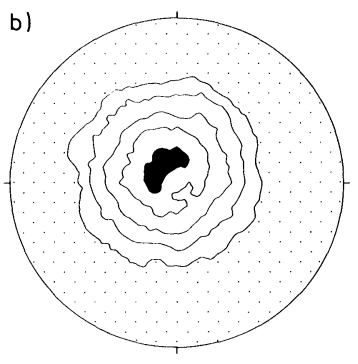

$1-2-3-4-5 \%$

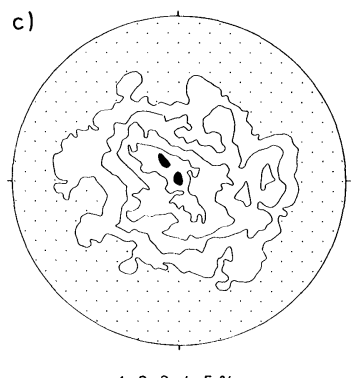

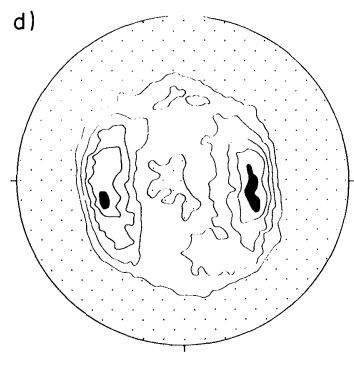

$1-2-3-4-5 \%$

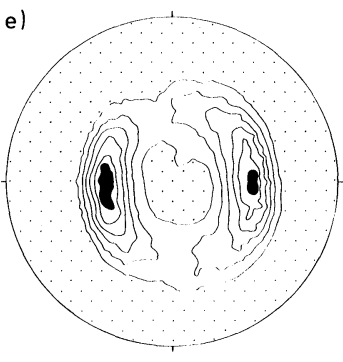

$1-2-3-4-5-6 \%$

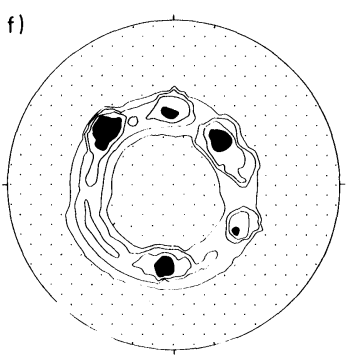

$1-3-5-7 \%$

Figure 5 Natural (10.4) pole figures of Precambrian high-grade hematite ores: (a) Low-grade metamorphic and unsheared quartz jaspilite (Morro de Urucum, Mato Grosso, Brazil; anisotropy $80^{\circ}$, homogeneity 3:3); (b) Low-grade metamorphic quartz jaspilite with broad central point maximum (Beeshoek, northern Cape Province, Republic of South Africa; anisotropy $50^{\circ}$, homogeneity $3: 2$ ); (c) Lowgrade metamorphic quartz jaspilite with scattered point maximum (Sishen mine, northern Cape Province, Republic of South Africa; anisotropy $40^{\circ}$, homogeneity $3: 2$ ); (d) High-grade ore with advanced preferred orientation caused by shearing (Cauê mine, Itabira district, Minas Gerais, Brazil; anisotropy $30^{\circ}$, homogeneity $3: 2$; cf. Figure le); (e) Strongly sheared high-grade ore from a shear band with high degree of preferred orientation and fiber-like texture resulting from pronounced extensional flow (Fábrica mine, Quadrilátero Ferrífero, Minas Gerais, Brazil; anisotropy $10^{\circ}$, homogeneity $3: 1$ ); (f) Extreme example of a strongly sheared high-grade ore with a quasi-monomineral texture (Aguas Claras mine, Quadrilátero Ferrífero, Minas Gerais, Brazil; anisotropy $10^{\circ}$, homogeneity $3: 3$; cf. Figure 1f). 
entire field of $80^{\circ}$ and show a rotative symmetry. The equivalent (10.4) poles are arranged in curved maxima at about $35^{\circ}$ to the centre of the diagram which is occupied by a broad area of lower frequency. This figure predicts a geometric configuration corresponding to textures of weak preferred orientation, as verified by jaspilites of the Urucum type (Figure 5a). With progressive anisotropy, i.e., by reducing the radius of the circle occupied by pole positions, the maxima more and more become arranged in a ring with outwardly and inwardly decreasing frequencies (Figure 4: $60^{\circ}$ to $40^{\circ}$ ). In all cases the effect of lower homogeneity is that of initially concentrating the pole positions to a point maximum $(3: 2)$ and then (3:1) of resolving this maximum into two elongated maxima exhibiting a butterfly-shaped configuration. Figure $5 \mathrm{~b}$ and $5 \mathrm{c}$ are natural examples of $3: 2$ textures at $50^{\circ}$ and $40^{\circ}$, respectively (samples from Beeshoek and Sishen mine). As yet these texture types have been registered only in jaspilites and primary high-grade ores stamming from rocks which suffered simple folding or/and ruptile deformation with no or weak effects of ductile shearing. Such conditions may be established in areas of regional lowtemperature metamorphism (cf. Müller et al., 1986, for discussion) or in enclaves of low-grade deformation within an environment of prograde metamorphism.

Anisotropies below $35^{\circ}$ are characteristic for samples from zones of intense deformation by simple shear to be encountered in areas of medium- to high-grade metamorphism at temperatures above $400^{\circ} \mathrm{C}$. Samples of such origin exhibit a penetrative foliation of schistosity with strong preferred orientation of tabular hematite (specularite) which is similar to that of mica. The (0001) poles are arranged more or less perpendicular to the foliation plane and simulate a fiber texture. The geometry of corresponding (10.4) pole figures is characterized by a central area lacking pole positions. This area broadens with progressive anisotropy (Figure $4: 30^{\circ}$ to $10^{\circ}$ ). The maxima of $3: 3$ textures show a ring-like arrangement of decreasing width (Figure 5f: $10^{\circ}$ texture of a strongly sheared high-grade ore from Aguas Claras mine). The ideal final stage at $0^{\circ}$, not yet registered in natural samples, would be a single-line ring with scattered (10.4) poles corresponding to a simple rotative texture symmetry with perfect parallelism of all $c$ axes. Decreasing homogeneity effects the (10.4) pole positions by arranging them in 
banana-shaped maxima which are symmetric to a line indicating the direction of principal shear (Figure 5d: 3:2 texture of high-grade ore from Cauê mine, Figure 5e: 3:1 texture of high-grade ore from Fábrica mine).

The present qualitative approach to a prediction of the fabric geometry of polycrystalline hematite reveals a striking coincidence of simulated and natural (10.4) pole figures. The decisive parameters of influence seem to be the position of $c$ axes in relation to the principal foliation plane of samples and varying degrees of anisotropy and homogeneity as to their spatial distribution. Yet a fully kinematic interpretation of the evolution of preferred orientation would require a better understanding of lattice gliding mechanisms and their effect on the configuration geometry of axes and faces. At temperatures of $25^{\circ} \mathrm{C}$ to $400^{\circ} \mathrm{C}$ and $400 \mathrm{MPa}$ confining pressure, deformation twinning on $\{r\}$ and $(c)$ and microfracturing was found to be the predominant mechanism (Hennig-Michaeli, 1976). Ramdohr (1980) reported translation on (0001) to be common above $400^{\circ} \mathrm{C}$. High-temperature deformation of synthetic polycrystalline $\mathrm{Fe}_{2} \mathrm{O}_{3}$ was demonstrated to be consistent with diffusion creep accompanied by grain-boundary sliding (Crouch, 1972), conditions which fall into the Cobble creep field of Atkinson's map of deformation mechanisms of hematite (1977).

The hematite ores, from which pole figures are described here, were formed under different conditions of regional metamorphism without significant post-deformational heating which would give rise to a pronounced recrystallization and weak grain anisotropy, as described from central Sweden (von Gehlen, 1960; Wagner et al., 1977). Deformation twins are rarely developed. The predominant mechanism of preferred orientation seems to be deformationinduced and controlled by varying strain. In the case of ores with weak orientation and low anisotropy, the foliation planes are equivalent to the compositional layering of the underformed rock and are due to pure shear (flattening). Under influence of increasing simple rotational shear discontinuity planes are generated which act as zones of pronounced ductile shear. These zones may correspond in position to the former bedding surfaces (lamination of itabirites) or may be newly formed shear zones (cleavage or thrust planes). The strain-induced (flattening) foliation plane initially will be at $45^{\circ}$ to the shear plane and with more intense deformation will be 
smeared into subparallelism with it, i.e., will become asymptotic to it. This geometric arrangement requires a mass mobilization parallel to the shear plane, that is shortening (compressional flow) in $Y$ or/and elongation (extensional flow) in $X$ (see Coward, 1976, for discussion). This explains why a strong mineral (elongation) lineation, which by increasing deformation approaches the shear direction $X$, is ubiquitous in all analysed ore samples. The effect of these processes on the preferred orientation of hematite is progressive recrystallization and planarity of the individual crystals and increasing parallelism of (0001) planes with the foliation plane.

In hematite ore of high anisotropy, which formed under conditions of temperatures above $400^{\circ} \mathrm{C}$ and simple shear, diffusion creep, grain-boundary gliding, and translation in (0001) seem to be the predominant mechanisms defining the different states of preferred orientation of hematite. In ores of weak crystallographic orientation, e.g. jaspilites, prismatic slip may be operative as well. This would correspond to the range of metamorphic temperatures calculated by Müller et al. (1986), which define the general environmental conditions. Yet it is the amount of imposed strain which influences the configuration of natural hematite fabrics.

\section{Acknowledgement}

This study is part of a terminated research program on direct reduction of high-grade hematite ores which was funded by the Arbeitsgemeinschaft Industrieller Forschung (AIF), and this support is gratefully acknowledged. The author is greatly indebted to R. Taugs for stimulating discussions and valuable suggestions which guided the course of the investigations. All measurements of natural ore textures were carried out by Prof. C. Esling and collaborators at the Laboratoire de Métallurgie Structurale of the Universite de Metz/France; the author expresses gratitude for this great help and a long-standing cooperation. J. Mager and W. Renner elaborated the initial version of the simulation program, and $\mathrm{Chr}$. Singewald assisted in the calculation of textures. I. Joss typed the manuscript and drafted the figures. These collaborative efforts are gratefully appreciated.

\section{References}

Ambs, H. (1966). Natürliche Hämatitgefüge-Untersuchungen zur plastischen Verformung von Hämatit in Korn und Gefüge. $N$. Jb. Miner., Mh., (1966), 225-245.

Astier, J. (1981). The growing importance of direct reduction in the iron ore business. Proceed. Metal Bulletin's 2nd Internation. Iron Ore Symposium Frankfurt, D1-D15. London: Metal Bulletin. 
Atkinson, B. K. (1977). The kinetics of ore deformation: Its illustration and analysis by means of deformation maps. Geol. Foeren. Stockholm Foerh., 99, 186-197.

Bunge, H.-J. (1981). Fabric analysis by orientation distribution function. Tectonophysics, 78, 1-22.

Chemale, F. (1987). Tektonische, lagerstättenkundliche und petrographische Untersuchungern im Eisenerzrevier Itabira, Minas Gerais, Brasilien. Dissertation, Technische Universität Clausthal.

Coward, M. P. (1976). Strain within ductile shear zones. Tectonophysics, 34, 181-197.

Crouch, A. G. (1972). High temperature deformation of polycrystalline $\mathrm{Fe}_{2} \mathrm{O}_{3} . J$. Am. Ceram. Soc., 55, 558-563.

Esling, C., Quade, H., Wagner, F. and Walde, R. (1981). Pesquisa textural de minério hematítico da jazida de Aguas Claras (MG) pelo método de difração de neútrons. Revista Brasileira de Geociências, 11, 84-90.

Evangelista, M. T. R. (1984). Struturelle und texturelle Untersuchungen in der Eisenerzlagerstätte Mutuca bei Belo Horizonte, Minas Gerais, Brasilien. Dissertation, Technische Universität Clausthal.

Gehlen, K. von (1960). Die röntgenographische und optische Gefügeanalyse von Erzen, insbesondere mit dem Zählrohr-Texturgoniometer. Beitr. Mineral. Petrol., 7, 340-388.

Guba, I. (1982). Tektonik, Texturen und Mineralogie der präkambrischen Eisenerze und Nebengesteinsserien der Lagerstätte Morro Agudo im NE des Quadrilátero Ferrifero/Minas Gerais, Brasilien. Dissertation, Technische Universität Clausthal.

Hackspacher, P. (1979). Strukturelle und texturelle Untersuchungen zur internen Deformation des Eisenreicherzkörpers der Grube "Aguas Claras" bei Belo Horizonte/Minas Gerais, Brasilien. Dissertation, Technische Universität Clausthal.

Hennig-Michaeli, Chr. (1976). Mikroskopische Gefügeuntersuchungen an experimentell und natürlich verformten Hämatiterzen. Dissertation, RWTH Aachen.

Hennig-Michaeli, Chr. (1977a). Mirroscopic structure studies of experimentally and naturally deformed hematite ores. Tectonophysics, 39, 255-271.

Hennig-Michaeli, Chr. (1977b). Dynamic interpretation of deformation twins in hematite. Geol. Foeren. Stockholm Foerh., 99, 208-215.

Hobbs, B. E. (1981). The influence of metamorphic environment upon the deformation of minerals. Tectonophysics, 78, 335-383.

Lindsley, D. H. (1965). Iron-titanium oxides. Carnegie Inst. Washington Year Book, 64, 144-148.

Lindsley, D. H. (1976). The crystal chemistry and structure of oxide minerals as exemplified by the Fe-Ti oxides. In Oxide minerals, Reviews in Mineralogy, 3, edited by D. Rumble, pp. L1-L60. Chelsea/Michigan: Mineralogical Society of America.

Mager, H. J., Quade, H. and Renner, W. (1985). Natural and simulated (10.4) textures of hematite ores. Fortschr. Miner., 63, 139.

Morris, R. C. (1985). Genesis of iron ore in banded iron-formation by supergene and supergene-metamorphic processes. A conceptual model. In Handbook of stratabound and stratiform ore deposits. Part IV. Volume 13. Regional studies and specific deposits, edited by K. H. Wolf, pp. 72-260. Amsterdam: Elsevier.

Müller, G., Schuster, A. and Hoefs, J. (1986). The metamorphic grade of banded iron-formations: Oxygen isotope and petrological constraints. Fortschr. Miner., 64, 2, 163-185. 
Neff, H. and Paulitsch, P. (1960). Röntgenographische Bestimmung der Hämatitregel in natürlichen Gefügen. N. Jb. Miner., Abh., 94, 1401-1410.

Pauling, 1. and Hendricks, S. B. (1925). The crystal structure of hematite and corundum. J. Am. Chem. Soc., 47, 781-790.

Quade, H. and Walde, R. (1982). Texturuntersuchungen an hämatitischen Reicherzen. Arch. Eisenhüttenwesen., 53, 85-89.

Ramdohr, P. (1980). The ore minerals and their intergrowth, 2nd edn. Oxford: Pergamon Press.

Ramdohr, P. and Strunz, H. (1967). Klockmann's Lehrbuch der Mineralogie, 15th edn. Stuttgart: Enke.

Rosière, C. A. (1981) Strukturelle und texturelle Untersuchungen in der Eisenerzlagerstätte "Pico de Itabira" bei Itabirito/Minas Gerais, Brasilien. Clausthaler Geowiss. Diss., 9. Clausthal-Zellerfeld: Institut für Geologie und Paläontologie.

Siemes, H. and Hennig-Michaeli, CH. (1985). Ore minerals. In Preferred orientation in deformed metals and rocks: An introduction to modern texture analysis, edited by H.-R. Wenk, pp. 335-360. New York: Academic Press.

Starkey, J. (1987). Analysis of orientation diagrams derived from a simulated quartz fabric. Can. J. Earth Sci., 24, 565-571.

Wagner, F., Esling, C., Baro, R. and Englander, M. (1977). Textures of iron oxide ores by neutron diffraction and topotactical relation. Z. Metallk., 68, 701-704.

Walde, R., Quade, H., Burghardt, O., Kortmann, H. and Bock, W. (1983). Beobachtungen bei der Reduktion von gebänderten Eisenerzen. Arch. Eisenhüttenwesen, 54, 7, 267-272. 